\section{A parent participation proposal: Benefiting from the field expert teacher parents on teaching of course subjects}

\section{Kerim Karabacak ${ }^{1}$}

\begin{abstract}
This research has been realized to determine whether students' academic success increases when teacher parents as expert in their fields teach courses instead of classroom teachers with the aim of giving a parent participation proposal. In the research, the study group includes $4^{\text {th }}$ grade elementary school students which has been realized experimentally in controlled pre-test and final test model. Success test developed by the researcher has been used as data collection instrument which is determined with sampling method with aimed study group in the research. Paired groups t-test has been user in the data analysis. According to the research findings, when field expert teacher parents enter the course and when these are compared with the courses which classroom teachers enter, it has been determined that academic success of the students increase at the same level. However, the result of permanence of the knowledge being higher has been reached when compared with the courses which classroom teachers enter. According to the results, it is proposed that field expert teacher parents should enter the courses of classroom teachers in teaching of some subjects. This also can be accepted as a new parent participation proposal.
\end{abstract}

Keywords: Parent participation, family participation, teacher parent, field expert parents.

(Extended English summary is at the end of this document)
Bir veli katılım önerisi: Alan uzmanı öğretmen velilerden derslerde faydalanma

\section{Özet}

$\mathrm{Bu}$ araşturma bir veli katulım önerisinde bulunmak amacı ile konu alanında uzman olan öğretmen velilerin sınıf öğretmeninin yerine ders vermesinin öğrencilerin akademik başarılarını arttırı arttırmadığını belirlemek için gerçekleştirilmiştir. Kontrollü ön test ve son test modelinde deneysel olarak gerçekleştirilen araștırmada, çalıșma grubu ilkokul 4. sınıf öğrencilerinden oluşmaktadır. Çalıșma grubu amaçlı örnekleme yöntemine göre belirlenmiş olan araşturmada veri toplama arac1 olarak araştırmacı tarafindan geliştirilen başarı testi kullanılmışır. Verilerin analizinde eşleştirilmiş gruplar t-testi kullanılmıştır. Araştırma bulgularına göre alan uzmanı öğretmen velilerin sınıf öğretmenlerinin yerine derslere girmesinin ögrencilerin akademik başarılarının, sınıf öğretmenlerinin girmiş oldukları dersler ile karşılaştırıldığında aynı düzeyde arttı̆̆ belirlenmiştir. Ancak öğrenilen bilgilerin kalıclloğ ise sınıf öğretmenlerinin girmiş oldukları derslere göre daha yüksek olduğu sonucuna ulaşılmıştır. Sonuçlara göre bazı konuların öğretiminde o alanda uzman öğretmen velilerin sınıf öğretmenlerinin derslerine girmesi önerilmektedir. Bu da yeni bir veli katılım önerisi olarak kabul edilebilir.

Anahtar Kelimeler: Veli katılımı, aile katılımı, öğretmen veli, alan uzmanı veliler.

\footnotetext{
${ }^{1}$ Assoc. Prof. Dr., Istanbul University-Cerrahpasa, Hasan Ali Yucal Education Faculty, Education Sciences, kerimk@istanbul.edu.tr
} 
Karabacak, K. (2019). Bir veli katılım önerisi: Alan uzmanı öğretmen velilerden derslerde faydalanma. Journal of Human Sciences, 16(4), 1026-1037. doi:10.14687/ihs.v16i4.5832

\section{Giriş}

Temel eğitim insan hayatında kısa bir dönemi kapsamasına rağmen, ilk y1lları öğrencilerin ailesinden bağımsız yaşama alışkanlı̆̆ını kazanması açısından önemlidir. İlkokula yeni başlayan çocuk ilk kez aile ortamının dışına çıkarak toplumun diğer üyeleri ile kaynaşmaya başlar. Ailenin bu süreçte çocuklarının eğitimine destek olmas1, okul ve öğretmenler ile iş birliği içerinde bulunması çocuklarının okula alışmasının yanı sıra onların okula olan tutumlarını ve akademik başarılarını olumlu yönde geliştirmelerine yardımcı olacaktır. Bu nedenle okulda, okul dişında veya evde yapılacak olan etkinliklere okul ve öğretmenlerin yönlendirmeleri ile ailelerin katılım göstermesi gerekir. Ailelerin okul ve öğretmenler ile çocuklarının eğitimi süresince iş birliği içerisinde olması veli (aile) katılımı olarak ifade edilir.

Cavkaytar'a göre (2004) aile katılımı, ailelerin eğitim kurumunun belirlediği akademik ve sosyal amaçları gerçekleştirebilmesi için yapılacak olan etkinlikleri planlama sürecinde, yönetiminde ve bu etkinliklerde aktif bir şekilde yer almasıdır. Öğrencilerin sosyal ve duygusal gelişimleri ile akademik başarıları üzerine olumlu etkisi bulunmasından (Ay ve Aydoğdu, 2016; Ule, Zivoder, Bois-Reymond, 2015; Akay ve Küçükkaragöz, 2014; Şad ve Gürbüztürk, 2013; Argon ve Kıyıc1, 2013; Şad, 2012; İpek, 2011; Sirvani, 2007; Gül, 2007; Beydoğan 2006; Broks, 2004; Çelenk, 2003) dolayı aile katılımı temel eğitim sürecinde son derece önemlidir. Önemli olmasından dolayı da Amerika, Belçika, Hollanda gibi birçok ülkede eğitim sürecince aile katıllımı yasal zorunluluk haline getirilmiştir (Ay ve Aydoğdu, 2016).

Topping'e göre (1995) aile katılımı velilerin öğretmenler ile birlikte çocuklarının eğitim sürecine katulımını, ev ödevlerini takip etmelerini, çocuklarının doğru bir şekilde yazdıklarını ve okuduklarını izleme, onların derslerde daha iyi öğrenmelerini sağlamak için ortam hazırlama, motive ve rehberlik etme gibi etkinlikleri içermektedir. Çakmak'a göre (2014) ise aile katılımı çok farklı şekillerde olabilir. Bu katılımlar, okulda yapılan etkinlikleri evde çocukları ile birlikte yapmak, gezilere yardımcı olmak, sınıfta öğrencilere şarkı öğretmek ve onlara şarkı söylemek, hikâye okumak, kendi kültürüne ve mesleğine ilişkin bilgi vermek, sınıfi ziyaret etmek ve gönüllü öğretmen yardımcısı olmak, çocukların kullanacağı araç-gereçleri hazırlamak, sınıftaki etkinliklerde el becerisi gerekterin (kesme, dikme, onarım) işleri yapmak, öğretmene aileler ile iletissimde ve onların katıllımda bulunmalarına yardımcı olmak ve evcil hayvanları sınıfa getirmek şekilde olabilir.

Aile katılımı üzerine çok sayıda araştırması bulunan Epstein'e göre (1995) aile katılımı ile ilgili farklı modeller bulunmaktadır. Epstein'in ileri sürmüş olduğu modellerden "çalışan küreler" (overlapping spheres) oldukça önemli modellerden birisi olarak kabul görmektedir. Çalışkan küreler modeline göre aile katılımı altı farklı türde gerçekleşmektedir. Bu altı katılım şekli aşağıldaki gibidir (Epstein, 1995; Epstein, Sanders, Simon, Salinas, Jansorn, ve Voorhis, 2002; Epstein, 2005):

- Anne-Babahk (Parenting), okul başarısına yönelik olarak çocuğun gelişimi ve eğitimi ile ilgili ev temelli etkinlikleri ve uygulamaları gerçekleştirmek,

- Iletişim (Communication), iletişim araçları ile (Telefon, e-posta, not kağıtları) aile ve okulöğretmen arasındaki bilgi alışverişinde bulunmak,

- Gönüllülïk (Volunteering), okula ekonomik, toplumsal vb. kaynakları sağlamak, okul/sınıf içinde gerçekleştirilecek etkinlik ve uygulamalarda yer almak,

- Evde ögrenme (Learning at home), okul ve sınıfta yürütülen çalışmalar ile ilgili öğrencilere verilen ödevlerin ve sorumlulukların evde nasıl yerine getirebileceğine ilişkin yardım ve bilgilendirmelere ilişkin uygulamalara katulmak.

- Karar verme (Decision making), okul ve sınıfın yönetim, eğitim ve öğretim süreçlerindeki karar verme sürecine dâhil olmak,

- Toplumla işbirliği (Colaborating with the community), toplumu ilgilendiren ve toplum yararina olan konularda okul tarafindan verilen bilgilendirmeler doğrultusunda toplumsal ilişki ve etkinlikleri desteklemek veya bu etkinliklere katılmak.

Lawson'a göre (2003), aile katılımı dört farklı düzeyde ele alınmaktadır. 
Karabacak, K. (2019). Bir veli katılım önerisi: Alan uzmanı öğretmen velilerden derslerde faydalanma. Journal of Human Sciences, 16(4), 1026-1037. doi:10.14687/jhs.v16i4.5832

- Birinci Düzey, ailenin evdeki eğitim ortamının yapılandırılmasını içerir. Bu düzeyde ailenin okulda alınan kararlara katılımı daha düşük seviyededir.

- İkinci Dürey, ailenin ders dışı, kırtasiye, kültürel ve çocukların gelişimi ile ilgili etkinliklere katulımını içerir.

- Ü̧̧йncü Dürey, ailenin sınıfta öğretmen yardımcısı gibi görev alması, öğretmen ile birlikte hareket etmesi, okuldaki birliklere ve komisyonlara katılması, karar verme süreçlerinde yer almasını içerir.

- Dördüncü Düzey, ailenin okuldaki düzenlemelere yardım etmesi, okulun gelişimini sağlayacak etkinliklere, stratejilere ve reformlara katılması ve okulda yaşanan sorunları ortadan kaldırmak için problem çözme sürecinde görev almasını içerir.

Ulusal ve uluslararası literatür incelendiğinde veli katılımına veya okul, öğretmen ve veli işbirliğine yönelik çok sayıda araştırmanın (Demircan, 2018; Yılmaz, İlkörücü ve Çepni, 2018; Çobanoğlu ve Babavan, 2017; Tümkaya, 2017; Ay ve Aydoğdu, 2016; Berger ve Riojaz-Cortez, 2016; Çağdaş, Özel, konca, 2016; Ule, Zivoder, Bois-Reymond, 2015; Aksu ve Karaçöp, 2015; Çalışkan ve Ayık, 2015; Çakmak, 2014; Ogelman, 2014; Şad ve Gürbüztürk, 2013; Akay ve Küçükkaragöz, 2013; Şad, 2012; Argon ve Kıyıc1, 2012; İpek, 2011; Erdoğan, Demirkasımoğlu, 2010; Çakmak, 2010; Can, 2009; Kartal, 2008; Gül, 2007; Sirvani, 2007; Beydoğan, 2006; Kocabaş, 2006; Broks, 2004; Aslan, Nural, 2004; Çelenk, 2003; Lawson, 2003; Sanders, 2001; Akkök, Ögetürk ve Kökdemir, Annak ve Çakın, 2000; Gökçe, 2000; Simon, 2000; Caplan, Hall, Lubin ve Fleming, 1997; Eccles ve Haold 1996) gerçekleştirildiği görülmektedir. Bu araştırmalardan sınıf seviyesi yükseldikçe veli katılımının azaldığını ortaya koyan (Simon, 2000; Caplan, Hall, Lubin ve Fleming, 1997) araştırmalara paralel olarak, okul öncesinden başlayarak üst kademelerine doğru aile katılımına yönelik araştırmaların da azaldığı görülmektedir. Özellikle araştırmaların çoğunluğu okul öncesinde gerçekleştirildiği (Ay ve Aydoğdu, 2016), ilkokul düzeyinde gerçekleştirilen araştırmaların (Çağdaş, Özel ve Konca, 2016; Ay ve Aydoğdu, 2016; Şad ve Gürbüztürk, 2013; Argon ve Kıyı11, 2012; Kartal, 2008; Gül, 2007; Akkök, Ögetürk ve Kökdemir, Annak ve Çakın, 2000; Gökçe, 2000; Akkök, Ögetürk ve Kökdemir, 1998; ) ise az sayıda olduğu söylenebilir. İlkokul düzeyinde gerçekleştirilen araştırmalar arasında öğretmen velilerin alanında uzman oldukları bir konuda sınıf öğretmeninin yerine sınıfa girip, uzman olduğu alana ilişkin öğrenme-öğretme etkinliklerini gerçekleştirdikleri araştırmalara rastlanmamıştır. Bu nedenle araştırma "konu alanında uzman olan öğretmen velilerin derse girmesinin ve o dersi öğretmenin yerine vermesinin öğrencilerin akademik başarılarını arttırıp arttırmadığını belirleyerek yeni bir veli katulım önerisi ortaya koymak amacı ile gerçekleştirilmiştir. Bu amaç çerçevesinde aşağıdaki problem ve alt problemlere cevap aranacaktır:

\section{Problem ve Alt Problemler}

Araştırmanın problem cümlesi, "Alan uzmanı olan öğretmen velilerin sınıf öğretmenin yerine temel eğitimde girmiş oldukları Fen Bilimleri derslerindeki öğrencilerin akademik başarısı artmakta mıdır?” şeklinde oluşturulmuştur. Alt problemler ise aşağıdaki gibidir:

1. Alan uzmanı öğretmen velilerin sınıf öğretmeninin yerine işlemiş oldukları Fen Bilimleri dersi konularındaki öğrencilerin son test başarı puanları ile sınıf öğretmeni tarafindan işlenmiş olan aynı konularındaki öğrencilerin son test başarı puanları arasında anlamlı bir fark var midir?

2. Alan uzmanı öğretmen velilerin sınıf öğretmeninin yerine işlemiş oldukları Fen Bilimleri dersi konularındaki öğrencilerin kalıcılık testi başarı puanları ile sınıf öğretmeni tarafından işlemiş olan aynı konudaki öğrencilerin kalıcılık testi başarı puanları arasında anlamlı bir fark var mıdır?

3. Alan uzmanı öğretmen velilerin sınıf öğretmeninin yerine işlemiş oldukları Fen Bilimleri dersi konularına ilişkin öğrencilerin son test başarı puanlanı ile kalıcılık testi başarı puanları arasinda anlamlı bir fark var midır? 
Karabacak, K. (2019). Bir veli katılım önerisi: Alan uzmanı öğretmen velilerden derslerde faydalanma. Journal of Human Sciences, 16(4), 1026-1037. doi:10.14687/jhs.v16i4.5832

4. Sınıf öğretmeninin işlemiş olduğu Fen Bilimleri dersi konularına ilişkin öğrencilerin son test başarı puanları ile kalıcılık testi başarı puanları arasında anlamlı bir fark vardır?

\section{Araştırmanın Önemi}

İstisnalar olmak ile birlikte günümüze kadar gerçekleştirilmiş olan çalışmaların veli katılımının, ağırlıklı olarak öğrencilerin okulda ve evdeki davranışlarını, akademik başarılarını öğretmenleri ile birlikte takip etmeleri üzerine odaklandığ1 görülmektedir. Diğer bir ifade ile araştırmaların çoğunlukla velilerin öğretmenler ile çocuklarının eğitim süreci boyunca iletişimde olmalarının önemi üzerine ve buna bağlı olarak öğrencilerin ders başarısını arttıracak dersleri iyi dinlemesini, derslerini çalışmasını, ev ödevlerini zamanında yapmasını sağlama, iyi bir öğrenci olması için davranışlarını kontrol altında tutma, sosyal aktivitelerde okula ve öğretmene destek olma konuları üzerine yoğunlaşmıştır. Bu çalışma ise veli katılımını farklı bir boyuta taşımaktadır. Araştırma alanında uzman olan öğretmen velilerin sınıf öğretmeninin derslerine girerek o dersi işlemesinin öğrencilerin akademik başarıları üzerindeki etkilerini ortaya koymak sureti ile veli katılımını farklı bir açıdan ele almaktadır. Başka bir ifade ile bu çalışma Epstein'in (1995) ileri sürmüş olduğu modellerden çalışkan küreler modelinin aile katılım türlerinden olan gönüllülük esasına dayılı olarak sınıf içinde gerçekleştirilen etkinliklere ve uygulamalara katılmaktan; Lawson'un (2003) üçüncü düzeyde ele aldı̆̆1 ailenin sınıfta öğretmen yardımcısı gibi görev almasından ve Çakmak'ın (2003) ifade ettiği şekli ile ailelerin gönüllü öğretmen yardımcısı olması ve sınıfta ailenin çeşitli etkinliklere katılmasından daha ileri bir düzeyde veli katıllımını içermektedir. Bu araştırmada alanında uzman olan ve pedagojik formasyon sahibi (öğretmen) aile bireylerinden birinin sinıf öğretmeninin yerine sınıfta ders işlemesinin öğrenci başarısına olan etkisini ortaya koymaya çalışmaktadır. Burada derse girecek olan kişi bir öğretmendir. Böyle bir özelliğe sahip olan bir aile bireyinden eğitimde faydalanılmasının öğrencilerin başarısını arttırabileceğini ortaya koyacak olması açısından araştırma önemli görülmektedir.

Ayrıca 2005-2006 eğitim öğretim yllından itibaren günümüze kadar Türkiye'deki okullarda uygulanan programlar üzerinde düzenlemeler yapıldığ1 ve son olarak da Temmuz 2017'de yeni programların oluşturulduğu düşünüldüğünde araştırma konusunun daha da önem kazandığı dikkate alınmalıdır. Bu nedenle araştırma, temel eğitim programlarının beklenen başarıyı elde etmesi ve kazanımların daha uzun süre kalıcılığını sağlayacağının düşünülmesi açısından da örnek bir çalışma olarak görülmektedir. Aynı zamanda elde edilen sonuçlar öğretmen yetiştirmede görev alan öğretim elemanlarına özellikle öğrenme öğretme etkinliklerinin düzenlenmesi konusunda farklı bir bakış açısı getireceği, hatta ders kitaplarında veli katılımı ile ilgili farklı bir bölüm oluşturulması gerektiği fikrini benimsetecek olması açısından da araştırmanın önemli olduğu düşünülmektedir.

\section{Sinirliliklar}

Araştırma ilkokullar ve Fen bilimleri dersi ile sınırlıdır.

\section{Yöntem}

\section{Araştırmanın Modeli}

Araştırma deney ve kontrol grubu olan kontrollü ön test ve son test modelinde gerçekleştirilen deneysel bir çalışmadır.

\section{Çalışma Grubu}

Deney ve kontrol grupları bir ilkokulun 4. sınıflarındaki 2015-2016 eğitim öğretim yllında öğrenim gören öğrencilerden oluşturulmuştur. Okulun belirlenmesinde amaçlı örnekleme yöntemlerinden tipik örnekleme (Büyüköztürk,, Çakmak, Aygün, Karadeniz ve Demirel, 2013) yöntemi kullanılmışır. Deney ve çalısma grubu olarak 4. sınıf seviyesinden iki şube belirlenmiştir. Bu iki şubenin belirlenmesinde daha önceden okul genelinde yapılmış olan deneme sınavlarındaki 
Karabacak, K. (2019). Bir veli katılım önerisi: Alan uzmanı öğretmen velilerden derslerde faydalanma. Journal of Human Sciences, 16(4), 1026-1037. doi:10.14687/jhs.v16i4.5832

fen bilimleri puanlarının sınıflara göre ortalamasının bir birine yakın olması dikkate alınmıştır. Ayrıca deneysel çalışmaya başlamadan önce ön test yapılarak başarı puanlarının ortalamasına bakılmıştır. Tablo 1'de verilen ön test sonuçlarına göre iki grubun başarı seviyesi arasında anlamı bir farkın olmadığı belirlenmiştir. Bu nedenle deney ve kontrol grubunun bir birine çok yakın akademik başarı seviyesine sahip öğrencilerden oluştuğu söylenebilir. Elde edilen ön test sonuçlarına göre deney ve kontrol gurubu atamaları yansız atama yolu ile kura çekilerek belirlenmiştir. Deney grubu 30 öğrenciden, kontrol grubu ise 29 öğrenciden oluşmaktadır.

Tablo 1. Ön test puanlarına göre gerçekleştirilen t testi sonuçları

\begin{tabular}{|c|l|c|c|c|c|c|}
\hline \multicolumn{2}{|c|}{ Değişkenler } & Ortalama & Ss & t & df & P \\
\hline \multirow{2}{*}{ Öntest } & Deney Grubu & 37,42 & 11,849 & \multirow{2}{*}{0,115} & \multirow{2}{*}{28} & \multirow{2}{*}{0,909} \\
\cline { 2 - 5 } & Kontrol Grubu & 37,24 & 7,744 & & & \\
\hline
\end{tabular}

\section{Deneysel Çalışma, Veri toplama Araçları ve Verilerin Toplanması}

Deneysel çalışma için 4. Sınıf Fen Bilimleri dersinin "Mikroskobik Canlılar ve Çevremiz/Canlılar ve Hayat" konu alanında yer alan "Mikroskobik Canlıları Tanıalım" konusu belirlenmiştir. Programda bu konuya ayrılan süre toplam beş ders saatidir. Bu dersin tercih edilmesinin nedeni her iki sınıftaki (deney ve kontrol grubu) öğrenci velileri arasında Fen Bilgisi öğretmeni olarak görev yapan öğretmenlerin yer almasıdır. 2015-2016 eğitim öğretim yılının ikinci döneminin başladığı ikinci hafta ön testler yapıldıktan sonra deney (30 öğrenci) ve kontrol (29 Öğrenci) gruplanı oluşturulmuştur. Deney grubundaki Fen Bilgisi öğretmeni olan veli ile irtibata geçilmiş ve bu grupta derse girebileceği zamana ilişkin bir plan oluşturulmuştur. Kontrol grubundaki sınıf öğretmenine bu planlama hakkında bilgi verilmiş ve onun da belirtilen tarih ve saatte aynı konuları işlemesi sağlanmıştır. Böylece, zamandan kaynaklanan olumsuzluklar ortadan kaldırılmaya çalışılmıştır. Alan uzmanı fen bilgisi öğretmeni olan veli konu ile ilgili materyal, ders araç ve gereçlerini hazırlayarak planlanan zamanda deneysel çalışmaya başlamıştır. Kontrol grubundaki çalışma ise sınıf öğretmeni tarafindan eş zamanlı olarak gerçekleştirilmiştir.

Verileri toplamak amacı ile okulda bir yıl önceki 4. Sinıflarda kullanılan konu alanını kapsayan tarama testi örnek alınarak araştırmacı ve öğretmenler tarafindan geliştirilen başarı testi oluşturulmuştur. Başarı testinin ilk hali dört seçenekli yirmi beş maddeden oluşmaktadır. Başarı testine ilişkin iki sınıf öğretmeni, iki fen bilgisi öğretmeni, biri fen bilgisi alanında görev yapan biri de eğitim programları ve öğretimi alanında görevli iki akademisyenin görüssleri alınarak son şekli verilmiştir. Yirmi beş maddeden oluşan başarı testi aynı okuldaki deney ve kontrol grubu dışındaki iki dördüncü sınıfa uygulanmıştır. Başarı testinin ön uygulamasından sonra test maddelerinin madde analizleri yapılmışır. Yapılan madde analizi sonuçlarına göre altı maddenin ayırt edicilik endeksi " 0,30 ” un altunda olduğu belirlenmiştir. Bu maddelerden " 0,28 " ayırt edicilik endeksine sahip olan maddenin, kapsam geçerliliği açısından önemli olmasından dolayı aynen kullanılmasına karar verilmiştir. Diğer beş madde testten tamamen çıkartılarak 20 maddeden oluşan nihai başarı testi oluşturulmuştur. Testteki maddelerin madde güçlük endeksleri " 0,20 ile 0,80 ” aralı̆̆nda değişmektedir.

Deneysel çalışmaya başlamadan önce ön test, uygulama bittikten sonra son test ve son testin yapıldığı tarihten altı hafta sonra kalıcılık testi hem kontrol hem de deney grubuna uygulanmıstır.

\section{Verilerin analizi}

Ön testten ve son testten elde edilen veriler elektronik ortamda SPSS programina aktarılmıştır. Öncelikle grupların puanlarının normal bir dağılım gösterip göstermediği belirlenmiştir. Yapılan analiz işlemlerine göre dağılımın normal olduğu tespit edilmiştir. Puanların normal dağılım göstermeleri nedeni ile verilerin analizinde iki grubun ortalamalarının karşılaştırılmasında tercih edilen eşleştirilmiş gruplar t-testi kullanılmıştır. Verilerin analizinde sırası ile; 
1. Deney ve kontrol gruplarının ön test puanları arasında fark olup olmadığını belirlemek için eşleştirilmiş gruplar t-testi,

2. Deney ve kontrol gruplarının son test puanları arasinda anlamlı fark bulunup bulunmadığını belirlemek için eşleştirilmiş gruplar $\mathrm{t}$ testi,

3. Deney grubunun son test ve kalıclik testi puanları arasinda anlamlı fark bulunup bulunmadığını belirlemek için eşleştirilmiş gruplar $\mathrm{t}$ testi,

4. Kontrol grubunun son test ve kalic1lik testi puanları arasında anlamlı fark bulunup bulunmadığını belirlemek için eşleştirilmiş gruplar t-testi istatistiksel işlemleri gerçekleştirilmiştir.

Ortalamalar arasında anlamlı farkın bulunduğunu belirlemek için " $\mathrm{p}<0,01$ ” anlamlılık düzeyi dikkate alınmıştır.

\section{Bulgular}

Bu bölümde deneysel çalışma tamamlandıktan sonra toplanan verilere göre gerçekleştirilen analiz sonuçlarında elde edilen araştırmanın alt problemlerine ilişkin bulgulara yer verilmiştir.

\section{Alt probleme Ait bulgular}

Araştırmanın birinci alt problemi "Alan uzmanı öğretmen velilerin sınıf öğretmeninin yerine işlemiş oldukları Fen Bilimleri dersi konularındaki öğrencilerin son test başarı puanları ile sınıf öğretmeni tarafindan işlenmiş olan aynı konularındaki öğrencilerin son test başarı puanları arasında anlamlı bir fark var midır?" şeklindedir. Tablo 2'de deney grubu ve kontrol grubu son test başarı puanlarının ortalamasına göre gerçekleştirilen t-testi sonuçları görülmektedir. Deney grubunun son test başarı puanı ortalaması ile kontrol grubunun son test başarı puanları arasında $\mathrm{p}<0,01$ anlamlılık düzeyinde anlamlı bir fark bulunmamıştır ( $\mathrm{t}=1,512, \mathrm{p}=0,142)$.

Tablo 2. Eşleştirilmiş Gruplar T Testi Sonuçları

\begin{tabular}{|c|c|c|c|c|c|c|}
\hline \multicolumn{2}{|c|}{ Değişkenler } & Ortalama & ss & $\mathrm{t}$ & $\mathrm{df}$ & $\mathrm{P}$ \\
\hline \multirow{2}{*}{ Son Test } & Deney Grubu & 79,31 & 11,080 & \multirow{2}{*}{1,512} & \multirow{2}{*}{28} & \multirow{2}{*}{0,142} \\
\hline & Kontrol Grubu & 77,75 & 9,504 & & & \\
\hline \multirow{2}{*}{ Kalıcılık Testi } & Deney Grubu & 77,59 & 10,404 & \multirow{2}{*}{9,108} & \multirow{2}{*}{28} & \multirow{2}{*}{$0,000^{*}$} \\
\hline & Kontrol Grubu & 65,52 & 7,560 & & & \\
\hline \multirow{2}{*}{ Deney Grubu } & Son test & 79,17 & 10,914 & \multirow{2}{*}{2,567} & \multirow{2}{*}{29} & \multirow{2}{*}{0,016} \\
\hline & Kalıcılik Testi & 77,50 & 10,234 & & & \\
\hline \multirow{2}{*}{ Kontrol Grubu } & Son test & 77,75 & 9,504 & \multirow{2}{*}{12,495} & \multirow{2}{*}{28} & \multirow{2}{*}{$0,000^{*}$} \\
\hline & Kalıcılik Testi & 65,52 & 7,560 & & & \\
\hline
\end{tabular}

\section{Alt Probleme Ait Bulgular}

Araştırmanın ikinci alt problemi "Alan uzmanı öğretmen velilerin sınıf öğretmeninin yerine işlemiş oldukları Fen Bilimleri dersi konularındaki öğrencilerin kalıcılık testi başarı puanları ile sınıf öğretmeni tarafindan işlenmiş olan aynı konudaki öğrencilerin kalııılık testi başarı puanları arasında anlamlı bir fark var midır?" şeklindedir. Tablo 2'den deney grubu kalıcllı testi puanları ile kontrol grubu kalıcılık puanları arasındaki t testi sonuçlarına göre anlamlı bir fark bulunmuştur $(t=9,108$, $\mathrm{p}=0,000)$. Ayn tablodan grupların ortalamaları incelendiğinde deney grubunun ortalamasının “77,59", kontrol grubunun ortalamasının "65,52" olmasından dolayı alan uzmanı öğretmen velilerin sınıf öğretmeninin yerine işlemiş oldukları derslerdeki öğrencilerin akademik başarıları kontrol grubundaki öğrencilere göre daha kalıcıdır.

\section{Alt Probleme Ait Bulgular}


Araştırmanın üçüncü alt problemi “Alan uzmanı öğretmen velilerin sınıf öğretmeninin yerine işlemiş oldukları Fen Bilimleri dersi konularına ilişkin öğrencilerin son test başarı puanları ile kalıcılık testi başarı puanları arasında anlamlı bir fark var mıdır?" şeklindedir. Deney grubunun kalıcılık testi puanları ile son test puanları arasında gerçekleştirilen Tablo 2'de yer alan t-testi sonuçlarına göre " $\mathrm{p}<0,01$ " anlamlılık düzeyinde anlamlı bir fark bulunmamıştır. Bu bulgu göstermektedir ki deney grubundaki öğrenciler öğrendiklerini daha az unutmaktadır.

\section{Alt Probleme Ait Bulgular}

Araştırmanın dördüncü alt problemi "Sınıf öğretmeninin işlemiş olduğu Fen Bilimleri dersi konularına ilişkin öğrencilerin son test başarı puanları ile kalıcılık testi başarı puanları arasında anlamlı bir fark vardır?" şeklindedir. Kontrol grubu son test ve kalıcllı testi puanları arasında gerçekleştirilen Tablo 2'deki t testi sonuçlarına göre anlamlı bir farkın bulunduğu belirlenmiştir $(\mathrm{t}=12,495, \mathrm{P}=0,000)$. Uygulamanın hemen ardından gerçekleştirilen son test puanlarına göre kalıcılık testi puanlarının anlamlı bir şekilde düşüş gösterdiği bulgusuna ulaşılmıştır.

\section{Sonuç ve Tartışma}

Fen Bilimleri ders konularının öğretiminde alanında uzman öğretmen velilerden faydalanılmasının öğrencilerin akademik başarısını artırıp artırmadığını belirmek amacı ile gerçekleştirilen bu çalışma deneysel bir araştırmadır. Çalışma grubu amaçlı örnekleme yöntemleri arasında yer alan tipik örneklemeye göre belirlenmiştir. Deney ve kontrol grubu yansız bir şekilde kura ile oluşturulmuştur. Verilerin toplanmasında araştırmacılar tarafindan geliştirilen başarı testi kullanılmış ve verilerin analizinde eşleştirilmiş grupların sahip olduğu ortalamaların karşılaştırılmasında kullanılan t-testi analiz işlemleri kullanılarak bulgulara ulaşılmışır. Elde edilen bulgulara göre aşağıdaki sonuçlara ulaşılmıştır:

Alan uzmanı öğretmen velilerin sınıf öğretmeninin yerine işlemiş oldukları Fen Bilimleri dersi konularındaki öğrencilerin son test başarı puanları ile sınıf öğretmeni tarafindan işlenmiş olan aynı konulardaki öğrencilerin son test başarı puanları arasında anlamlı bir fark yoktur. Beklenti alan uzmanı velilerin girmiş oldukları derslerdeki öğrencilerin başarılarının daha yüksek olacağı yönünde iken ulaşılan sonuç öğrencilerin başarılarında bir farkın olmadığı yönündedir. Başka bir ifade ile alan uzmanı öğretmen velilerin derse girmesi ile sınıf öğretmenlerin alışıla gelmiş şekli ile derslerini işlemeleri öğrencilerin başarılarını eşit düzeyde arttırmaktadır.

Alan uzmanı öğretmen velilerin sınıf öğretmeninin yerine işlemiş oldukları Fen Bilimleri dersi konularındaki öğrencilerin kalıcılık testi başarı puanları ile sınıf öğretmeni tarafından işlenmiş olan aynı konulardaki öğrencilerin kalıcılık testi başarı puanları arasında anlamlı bir fark vardır. Alan uzmanı öğretmen velilerin girmiş oldukları derslerdeki öğrencilerin öğrenmeleri, sınıf öğretmenlerinin alışıla gelmiş şekli ile işlediği derslerdeki öğrencilerin öğrenmelerine göre daha kalıcıdır. Alan uzmanı öğretmen velilerin sınıf öğretmeninin yerine işlemiş olduklan Fen Bilimleri dersi konularına ilişkin öğrencilerin son test başarı puanları ile kalıcılık testi başarı puanları arasında anlamlı bir fark yoktur. Başka bir ifade ile alan uzmanı öğretmen velilerin girmiş oldukları derslerde öğrencilerin öğrendiklerinin üzerinden zaman geçmesine rağmen çok az hatırlayamadıkları sonucuna ulaşılmıştır. Sınıf öğretmeninin alışıla gelmişs şekli ile işlemiş olduğu Fen Bilimleri dersi konularına ilişkin öğrencilerin son test başarı puanları ile kalıcılık testi başarı puanları arasında anlamlı bir fark vardır. Bu fark sınıf öğretmenlerinin vermiş oldukları derslere ilişkin öğrencilerin öğrenmelerinin ardından üzerinden zaman geçtiğinde daha çabuk unuttuklarını ortaya koymaktadır.

Elde edilen sonuçlara göre alanında uzman olan öğretmen velilerinin derslere katılarak dersleri işlemeleri, sınıf öğretmenlerinin aynı ders konularını işlemeleri ile karşılaştırıldığında, öğrencilerin akademik başarıları arasında fark yaratmamaktadır. Ancak öğrenilenler sınıf öğretmenlerinin işlemiş oldukları sınıflara göre daha kalıcıdır. Bu da alan uzmanı öğretmen velilerin ders verdiği sınıflardaki öğrencilerin akademik başarılarına süreklilik kazandırdığı sonucunu ortaya koymaktadır. Bu durum doğal olarak aile katılımının öğrencilerin akademik başarısını attırdığını ortaya koyan Ay ve Aydoğdu, (2016) Ule, Zivoder ve Bois-Reymond (2015), Akay ve 
Küçükkaragöz (2014), Şad ve Gürbüztürk (2013), Argon ve Kıyıc1, (2013), Gül (2007) ve Beydoğan'ın (2006) çalışmalarını destekler niteliktedir. Ancak onların çalışmaları daha çok velilerin çocuklarının eğitimini yakından takip etmiş olmaları ile ilgilidir. Bu çalışma ise alan uzmanı öğretmen velilerin dersin konularını sınıf öğretmeni gibi derse girerek anlatmasını içermesinden dolayı farklılık göstermektedir.

\section{Öneriler}

Araştırmada ulaşılan sonuçlara göre aşağıdaki önerilerden bulunulmuştur:

1. Sonuç itibari ile temel eğitimde öğretmenler, öğretmen velilerinden derslerinde onların uzmanlık alanlarına göre faydalanabilir. Böylece, öğrencilerin öğrendiklerinin daha kalıcı olmasını sağlayabilirler. Birçok veli katılım türlerinde olduğu gibi alan uzmanı öğretmen velilerden ders konularının öğretiminde faydalanma sadece anneler ile sinırlı kalmamalıdır. Bu durumda uzmanlık alanlarına göre babalar (Tümkaya, 2017), abi veya ablalardan öğretmen olanlarından faydalanılabilir. Okullar, velilerin katılımını attırmaya yönelik çalışmalarını (Çobanoğlu ve Badavan, 2017) alan uzmanı öğretmen velilerden faydalanma konusu üzerine odaklayabilir. Bu konuda okullar öğretmen velilerin özelliklerine göre derslere katılım programları organize edebilirler.

2. Literatürde yer alan çocuklarının eğitimine veli katıllımı örnekleri (Epstein, 1995; Lawson, 2003; Çakmak, 2003; Aslan ve Nural, 2004) arasına "alan uzamanı öğretmen velilerin sınıfa girerek ders konularının öğretimi” dâhil edilmelidir. Böylece veli katılımları sadece okula, öğretmene ve öğrenciye yardımcı olmaktan daha ileri bir düzeye taşınabilir. Bu uygulama Aslan ve Nural'ın (2004) ifade ettiği “etkili ve başarılı okula-aile işbirliğini oluşturmada" da son derece önemli olabilir.

3. Ailelerle bağlantı kurma ve ailelerle kolay etkileşim atmosferi oluşturma okulların sorumluluğundadır (Epstein, 1995). Ancak Milli Eğitim Bakanlığ1 alanında uzman olan öğretmen velilerin derslerde faydalanılması konusunda okul yönetimlerine ve öğretmenlere gerekli kolaylığı sağlayacak yasal düzenlemelerde buluna bilir. Ayrıca yasal düzenlemelerde bu özelliklere sahip velilerden faydalanılması için önerilere de yer verebilir.

4. Sağlık meslek lisesinde sağllklı beslenme konusunda ders veren bir öğretmen veli derslere girerek sağlıklı beslenme konusunu işleyebilir. Beden eğitimi öğretmeni olan bir veli egzersizin önemini, ticaret meslek lisesinde maliye derslerine giren öğretmen bir veli vergi vermenin önemini öğrencilere öğretebilir. Böylece öğrenciler en güncel bilgileri alanında uzman olan kişilerden öğrenebilir.

5. Öğretmenlerin hizmetiçi eğitimlerinde, seminer çalışmalarında ve eğitim fakültelerinde öğretim yöntem ve tekniklerinin kapsamına, alan uzmanı öğretmen velilerden derslerde faydalanılması konusuna yer verilebilir.

6. Eğitim fakültelerinde görev yapan akademisyenler gerek derslerinde gerekse yazmış oldukları ders kitaplarında bu konuyu içeren anlatımlarda bulunabilirler.

Araştırma sürecinde ve sonuçlarına bağlı olarak gelecekte yapılabilecek diğer araştırmalara ilişkin öneriler ise şu şekildedir:

1. Bu araştırma nicel araştırma yöntemleri arasında yer alan deneysel bir araştırmadır. Nicel verilerin nitel veriler ile desteklenebileceği karma araştırma yöntemleri kullanılarak benzer araştırmalar gerçekleştirilebilir. Örneğin, deneysel çalışmanın yanı sıra gözlem ve görüşmeye dayalı veri toplama tekniklerinin kullanıldığı nitel araştırmalar ile öğrencilerin ders esnasında ilgileri, tutumlanı, sorduklanı soruların niteliği ve sayısı hakkında bilgi sahibi olunabilir.

2. $\mathrm{Bu}$ araştırmanın benzeri farklı dersler için farklı öğretim kademelerinde gerçekleştirilebilir. 
Karabacak, K. (2019). Bir veli katılım önerisi: Alan uzmanı öğretmen velilerden derslerde faydalanma. Journal of Human Sciences, 16(4), 1026-1037. doi:10.14687/ihs.v16i4.5832

3. Ayrıca derslere ait konuların kapsamı genişletilerek ve daha geniş zamana yayarak araştırmalar gerçekleştirilebilir.

\section{Kaynakça}

Ahioğlu-Lindberg, N. (2014). Eğitim fakültesi son sınıf öğrencilerinin aile kattlımı ile ilgili görüşleri. Kuram ve Uygulamada Ë̈itim Bilimleri, 14(4), 1339-1361.

Akay, Y., Küçükkaragöz, H. (2014). Aile katıllımlı performans görevlerinin ilköğretim 5. Sınıf öğrencilerinin matematik dersi erişi ve tutumlarına etkisi. Turkish Studies - International Periodical For The Languages, Literature and History of Turkish or Turkic, 9 (5), 4766.DOİ:http://dx.doi.org/10.7827/TurkishStudies.6586

Akkök, F., Ögetürk, B., Kökdemir, H. (1998). İlköğretimde aile katılımı. Ankara: TED Anakara Koleji Eğitim Vakfı Yayını, 1: 14-18.

Akkök, F., Ögetürk, B., Kökdemir, H., Annak, Ş., ve Çakın, A. G. (2000). “ilköğgretimde Aile Katılım Programının Değerlendirilmesi”. TED Ankara Koleji Dergisi, 1(3), 5-9.

Aksu, F. F. ve Karaçöp, A. (2015). Öğrencilerin Ev Temelli Fen Öğrenme Etkinlerine Aile Katılımı. Erzincan Üniversitesi Ë̆itim Fakëiltesi Dergisi, 17(2), 456-476. DOİ.: 0.17556/jef.52040.

Argon, Ş. ve Kıyıcı, C. (2012). İlköğretim Kurumlarında Ailelerin Eğitim Sürecine Katılımlarına Yönelik Öğretmen Görüşleri. Dicle Üniversitesi Ziya Gökalp Ë̈itim Fakültesi Dergisi, 19, 80-95.

Arslan, Ü. ve Nural, E. (2004). Okul Öncesi Eğitiminde Okul-Aile İşbirliğinin Önemi, Milli Eğtim, 162, $99-108$.

Ay, T. S. ve Aydoğdu, B. (2016). Sınıf Öğretmenlerinin Aile Katılımlanına Yönelik Görüşleri. Adryaman Üniversitesi Sosyal Bilimler Enstitïsü Dergisi, 23, 262-290.

Berger, E. H. \& Riojaz-Cortez, M. (2016). Parents as Partners in Education Families and Schools Working Together. USA: Pearson

Beydoğan, H. Ö. (2006). Ailelerin Eğitim Sürecine Kattlımına Yönelik Modeller ve Yaklaşımlar. Gaz̧i Üniversitesi Kirş̧ehir Ë̆gitim Fakültesi Dergisi, 7(1), 75-90.

Brooks, J, E. (2004). Family Involvement In Early Childhood Education : A Descriptive Study Of Family Involvement Approaches And Strategies In Early Childhood Classrooms, Dissertation Abstracts International, 65(08), 2890A. (UMI No. 3142799), University Of South Caroline.

Büyüköztürk, Ş. (2012). Veri Analizi El Kitabı (16. Baskı). Ankara: Pegem akademi.

Büyüköztürk, Ş., Çakmak, E. K., Akgün, Ö. E., Karadeniz, Ş., Demirel, F. (2013). Bilimsel araştırma yöntemleri. Ankara: Pegem Akademi.

Can, B. (2009), Eğitim Programında Veli Katılımı, 8. Ulusal Sınıf Öğretmenliği Sempozyumuenda sunulan bildiri, Eskişehir Osmangazi Üniversitesi.

Caplan, J., Hall, G., Lubin, S., Fleming, R. (1997). Literature Review of School-Family Partnership. North Central Regional Educational Laboratory.

Çağdaş, A., Özel, E. ve Konca, A. S. (2016). İlkokul Başlangıcında Velilerin Aile Katılım Düzeylerinin İncelenmesi. Eg̈itimde Kuram ve Uygulama, 12 (4), 891-908.

Çakmak, Ö. Ç. (2010). Okulöncesi Eğitim Kurumlarında Aile Katılımı. Abant İzæet Baysal Üniversitesi Sosyal Bilimler Enstitïsü Dergisi. 1(10), 1-17.

Çalışkan, N. ve Ayık, A. (2015). Okul Aile Birliği ve Veliler İle iletişim. Ahi Evran Üniversitesi Sosyal Bilimler Enstitïï̈ Dergisi, 1 (2), 69-82.

Çelenk, S. (2003). Okul-Aile İşbirliğgi ile Okuduğunu Anlama Arasındaki İlişki, Hacettepe Üniversitesi Eğitim Fakültesi Dergisi, 24, 3-39.

Çobanoğlu, F. ve Badavan, Y. (2017). Başarı Okulların Anahtarı: Etkili okul Değişskenleri. Pamukkeale Üniversitesi Sosyal Bilimler Enstituisü Dergisi, 114-134. DOİ: 10.5505/pausbed.2017.24650

Demircan, H. Ö. (2018). Okulöncesi Eğitimde Aile Kattlımı Sistemini Geliştirmek: Aile Bağllliğı, Ortaklı̆̆1, Katılımı ve Eğitimi. İlköğretim Online, 17(4), 1-19.

Epstein, J.L., Sanders, M.G., Simon, B.S., Salinas, K.C., Jansorn, N.R., Voorhis, F.L.V. (2002). School, Family, and Community Partnerships: Your Handbook for Action. (2nd Ed.). Thousand Oaks, California: Corwin Press, Inc.

Epstein, J. L. (2008). Improving family and community involvement in secondary schools. Principal Leadership, 8 (2), 16-22.4 
Karabacak, K. (2019). Bir veli katılım önerisi: Alan uzmanı öğretmen velilerden derslerde faydalanma. Journal of Human Sciences, 16(4), 1026-1037. doi:10.14687/ihs.v16i4.5832

Epstein J.L., Jansorn. N.R. (2004). School, family and community partnerships link the plan. The Education Digest, 69 (6), 19-23.

Epstein, J. L. (1995). School/Family/Community Partnerships: Caring for the children we share. Phi Delta Kappan, 76 (9), 701-712.

Erdoğan, C.. Ve Demirkasımoğlu, N. (2010). Ailelerin Eğitim Sürecine Kattlımına İlişkin Öğretmen ve Yönetici Görüşleri. Kuram ve Uygulamada Eğitim Yönetimi, 16(3), 399-431.

Gökçe, E. (2000). “İlköğretimde Okul Aile İşbirliğinin Geliştirilmesi”. Pamukkale Üniversitesi Eğitim Fakültesi Dergisi, 7, Özel Say1.

Gül, G. (2007). “Okuryazarlık Sürecinde Aile Katılımının Rolü”. Ankara Üniversitesi Eğitim Bilimleri Fakültesi Özel Ë̈itim Dergisi, 8 (1) 17-30.

İpek, C. (2011). Velilerin Okul Tutumu ve Eğitime Katılım Düzeyleri İle Aileye Bağlı Bazı Faktörlerin İlköğretim Öğrencilerinin Seviye Belirleme Sınavları (SBS) Üzerindeki Etkisi. Pegem Eğitim ve Öğretim Dergisi. 1(2), 69-79.

Kartal, S. (2008). İlk ve Ortaöğretim Kurumların Velilerin Okul Yönetimine Katllımı. Ahi Evran Üniversitesi Kirşehir Ë̆itim Fakültesi Dergisi, 9 (1), 23-30.

Kocabaş, E. Ö. (2006). Eğitim Sürecinde Aile Katılımı: Dünyada ve Türkiye'deki Çalışmalar. Türk Psikolojik Çalssma ve Rebberlik Dergisi, 3(26), 143-153.

Lawson, M. A. (2003). School-family relations in context: parent and teacher perceptions of parent involvement. Urban Education, 38, 77-133.

Sanders, M.G. (2001). Schools, families, and communities partnering for middle level students' success. NASSP Bulletin, 85, 627.

Sirvani, H. (2007). The Effect of Teacher Communication With Parents On Students'Mathematics Achivement, American Secondary Education, 36 (1), 31-47.

Şad, S.N. (2012). Investigation of Parental Involvement Tasks as Predictors of Primary Students' Turkish, Math and Science \& Technology achievement. Eurasian Journal of Educational Research, 49, 173-196.

Şad, S. N., Gürbüztürk, O. (2013). “İlköğretim Birinci Kademe Öğrenci Velilerinin Çocuklarının Eğitimine Katılım Düzeyleri”. Kuram ve Uygulamada Eğitim Bilimleri Dergisi, 13(2), 993-1011.

Topping, K. J. (1995). Paired Reading, Spelling and Writting:Handbook for Teachers and Parents London: Cassell.

Tümkaya, S. (2017). Velilerin Okulda Eğitime Katılım Türlerinin Bazı Değişkenlere Göre İncelenmesi. Cukuroava Üniversitesi Sosyal Bilimler Enstitüsü Dergisi, 26 (2), 83-98.

Ule, M., Zivoder, A., \& Bois-Reymnd, M. (2015). 'Simply the best for my children': patterns of parental involvement in education. International Journal of Qualitative Studies in Education, 28(3), 329-348.

Yılmaz, G., İlkörücü Ş. Ve Çepni, S. (2018). Aile Katılımlı Fen Etkinliklerinin 5-6 Yaş Grubu Çocukarının Temel Bilimsel Süreç Becerilerine Etkisi. PEGEM Eğitim ve Öğretim Dergisi.8(4), 878903.

Weber, A. (2010). Can family involvement improve educational outcomes in developing countries?. [Online]: Retrieved on 12-December-2010, at URL: http://hdl.handle.net/10419/37533

\section{Extending English Summary}

Collaboration of family, school and teacher is extremely important in student's academic success. Because of this reason, the importance of family participation has been presented in many researches. Different participation types of parents in education of the children exist. These types are given below.

- Parenting, to realize home based activities and implementations related with the development and education of the child for school success,

- Communication, to make information exchange between family and school-teacher with communication devices (telephone, e-mail, note cards), 
- Volunteering, to provide economical, social, etc sources for the school, to take place in activities and implementations to be realized at home/school,

- Learning at home, to participate in the implementations related to help and informing about how responsibilities and assignments given to the student related with the studies at school and in the classroom should be realized.

- Decision making, to be included in decision making process on management of classroom and school and in education and teaching process,

- Collaborating with the community, to support social relationships and activities in the direction of informing of school on the subjects beneficial for the community and taking interest of the community or to participate in these activities.

\section{Purpose}

The research does not determine whether students' academic success increases when teacher parents as expert in their fields enter the courses and teach courses instead of classroom teachers, it has been realized with the aim of proposing a parent participation type. In the frame of this aim, answers will be found for the problems and sub-problems given below:

The problem has been established as "Does the success of the students increase in Science courses which teacher parents as expert in their fields enter instead of classroom teachers in basic education?" Sub-problems are given as below:

1. Is there a difference between the academic success grades of experimental group and the academic success grades of control group after the implementation?

2. Is there a difference between permanence test success grades of experimental group and the permanence test success grades of control group?

3. Is there a difference between the success grades and the permanence test success grades of experimental group after the implementation?

4. Is there a difference between the success grades and the permanence test success grades of control group after the implementation?

\section{Method}

The study group is established from $4^{\text {th }}$ grade students in the research which is realized in controlled pre-test and final test model with experimental and control group. Two branches which do not have difference between success levels in $4^{\text {th }}$ grades have been determined by draw as control and experimental group. The study group has been determined according to typical sampling from aimed sampling methods. Science teachers being expert in their fields have entered the classroom as experimental group. Classroom teachers entered the courses as control group. A success test including 20 items and developed by the researcher has been used as data collection instrument. The success test has been implemented for every group before and after the study and six weeks after the study had finished. Coupled groups t-test has been used in the analysis of the data.

\section{Findings}

A meaningful difference has not been found between the success grades of experimental group and control group after the implementation according to the findings of statistical analysis related to first sub-problem. A difference has been found between permanence test grades of experimental group and control group students related to second sub-problem. According to permanence test analysis, grades of experimental group are higher. A meaningful difference has not been found between success test grades and permanence test grades after the implementation of experimental group. But, a meaningful difference has been found between success test grades and 
permanence test grades after the experimental study of control group. It has been determined that permanence test grades of control group decreased meaningfully.

\section{Conclusion \& Discussion}

According to the findings, it has been determined that there is not a meaningful difference between the success grades of the students in experimental group which teacher parents as expert in their fields enter and success grades of the control group which the classroom teacher has entered after the implementation. In other words, success grade of two groups are at the same level. So it has been reached as a result that success grade of the students in the courses which teacher parents as expert in their fields enter and which the classroom teacher has entered are at the same level. However, learning of the students in the courses which teacher parents as expert in their fields is more permanent than the learning of the students which the classroom teacher has entered. There is not a meaningful difference between final test success grades and permanence success test grades of the students in which teacher parents as expert in their fields enter Science courses instead of classroom teachers. In other words, it has been reached as a result that the students did not forget the subjects they learned although a long time passed over in the courses which teacher parents as expert in their fields entered. There is a meaningful difference between final test success grades and permanence success test grades of the students related to Science subjects which classroom teacher gave with traditional methods. This difference presents that the students forget the things they learn more easily when a long time passes over on the subjects which their classroom teachers teach.

\section{Suggestions}

1. The teachers can benefit from teacher parents according to their expertise fields in basic education. So, they can provide the sustainability of the students' learning. The schools can organize participation programs in the courses according to the features of teacher parents on this subject.

2. "Teaching course subjects by parent teachers expert in their fields by entering the classroom" should be included in the samples of parent participation in the education of children taking place in the literature. By this way, parent participation can be removed to higher levels from only helping school, teacher and student.

3. Ministry of National Education can make legal arrangements providing necessary easiness for school management and teachers on benefiting from parent teachers in the courses in their expert fields.

4. A teacher parent giving course on healthy nutrition in a health vocational school can teach the subject of healthy nutrition by entering the courses, a sports teacher as a parent can teach the importance of exercise.

5. Benefiting from field expert parent teachers can take place in in-service education, seminar studies of the teachers and teaching method and techniques in educational faculties.

6. The academicians in educational faculties can make explanations both in their course books and in their courses which they give. 